\title{
Study the inheritance of branching behaviour and bearing pattern in clusterbean (Cyamopsis tetragonoloba (L.) Taub.)
}

\section{MK Choudhary, Ramavtar Sharma, HR Mahla, D Singh \& DK Saroliya}

Journal of Agriculture and Ecology

Volume-12 (December, 2021) ISSN: 2456-9410

\section{Journal of}

Agriculture and

ISSN: 2456-9410

Volume: 12

Journal of Agriculture and Ecology (2021) 12: 94-97 http://doi.org/10.53911/JAE.2021.12209 


\author{
Study the inheritance of branching behaviour and bearing pattern in \\ clusterbean (Cyamopsis tetragonoloba (L.) Taub.) \\ MK Choudhary ${ }^{1} \unrhd$, Ramavtar Sharma ${ }^{2}$, HR Mahla $^{2}$, D Singh ${ }^{1} \&$ DK Sarolia ${ }^{3}$ \\ ${ }^{I}$ Division of crop improvement, ICAR-CIAH, Bikaner-334006 \\ ${ }^{2}$ Division III, ICAR-CAZRI, Jodhpur-342003 \\ ${ }^{3}$ Division of crop production ICAR-CIAH, Bikaner-334006 \\ Corresponding author: MK Choudhary,Email: mahichouhary75@gmail.com
}

\section{Article Info \\ Article history \\ Received: 15 November 2021 \\ Accepted: 28 December 2021 \\ Available online: 31 December 2021}

\section{Key Words:}

Inheritance, Clusterbean, Segregating population, Chi-square method, monogenic inheritace, Polymeric gene action, Supplementry gene action.

\begin{abstract}
The present study was carried out to know about inheritance of two characters namely branching behavior and bearing pattern in clusterbean [Cyamopsis tetragonoloba (L.) Taub] in $\mathrm{F}_{2}$ segregating population. The initial experimental material consisted of $F_{1}$ seeds of three different crosses along with parents of clusterbean viz., F5 × RGC-1066, PNB $\times$ CAZG-1610-3, IDB-29-2 $\times$ BSL $(11 \times 15)$. The segregating progenies were raised at 50 $\mathrm{cm}$ row to row and $20 \mathrm{~cm}$ plant to plant spacing. All the $\mathrm{F}_{2}$ segregating plants of a cross were tagged and observations were recorded periodically till confirmation of the phenotype. The statistical analysis done by chi square method to find the goodness of fit for genetic ratio for different gene action involved in these segregating populations. The present study revealed that the branching behavior was controlled by two pairs of genes interacting in different pattern in two segregating $\mathrm{F}_{2}$ population viz., $\mathrm{PNB} \times \mathrm{CAZG}-16$ 10-3 (9:6:1) exhibited polymeric gene action, F5 × RGC-1066 (9:3:4) exhibited with supplementary gene action, while IDB-29-2 $\times$ BSL (3:1) branching and bearing pattern controlled by one pair of gene which exhibited monogenic inheritance.
\end{abstract}

Copyright (C2021 Choudhary et al., This is an open access article published under the terms of the Creative Commons Attribution License, which permits unrestricted use, distribution, and reproduction in any medium, provided the original work is properly cited.

Preferred citation: Choudhary MK, Sharma R, Mahla HR, Singh D \& Sarolia DK. 2021. Study the inheritance of branching behaviour and bearing pattern in clusterbean (Cyamopsis tetragonoloba (L.) Taub.). Journal of Agriculture and Ecology, 12: 9497; http://doi.org/10.53911/JAE.2021.12209.

\section{Introduction}

Guar (Cyamopsis tetragonoloba L.) as a legume crop of warm season with the deep and well-developed root system is drought tolerant which is cultivated mainly as a rainfed crop in arid and semi-arid areas. Guar has been traditionally used as a vegetable, livestock feed and a green manure crop in agriculture. It could be cultivated in poor and marginal lands and requires lower agronomic inputs. As a grain legume, it is able to symbiotic nitrogen fixation. Therefore, it can improve the soil quality in a cost-effective and natural way as a consequence the yield of subsequent crops. Although cluster bean is a minor crop but due to its better and finer guar gum qualities it is considered as an important cash crop for industrial gum production (Hymowitz \& motlock 1963; Sharma \& Gummagolmath 2012; Pathak \& Singh 2010). 
In agriculture guar gum is utilized as water retainer, soil aggregate and anticrusting agent. Guar gum has also greater utility in pollution control and acts as absorbent in waste water treatment in textile industry as flocculating and exchanging agent (Mahalonobis 1936). A mature clusterbean seed is composed of three parts: germ (43-47\%), endosperm (35-42\%), and seed coat (14-17\%). About $80-90 \%$ of the endosperm is composed of highly viscous water-soluble hetero-polysaccharide called gaur gum (or) galactomannan, having a 1:2 ratio of galactose to mannose. Young pods are good source of protein, carbohydrate, vitamins ('A' and ' $C$ '), and important minerals like calcium and iron (Kumar \& Singh 2002). The crop due to cleistogamous nature is considered strictly self pollinated, however, out crossing to the tune of 0.5 to $7.9 \%$ has been reported (Saini et al. 1981). Understanding the inheritance of traits is an important step in plant breeding to augment such traits. This allows efficient incorporation of inherited desirable traits in the well-adapted lines/varieties with higher production potential. This study investigates the inheritance of the two characters branching and bearing habit (qualitative) in cluster bean.

\section{Materials and Methods}

The initial experimental material consisted of $F_{1}$ seeds of three different crosses along with parents of clusterbean [Cyamopsis tetragonoloba (L.) Taub] viz., F5 $\times$ RGC1066, PNB $\times$ CAZG-16-10-3, IDB-29-2 × BSL (11X15), were provided by the guar improvement project executed at the ICAR-
CAZRI, Jodhpur. The segregating progenies were raised at $50 \mathrm{~cm}$ row to row and $20 \mathrm{~cm}$ plant to plant spacing for study branching and bearing pattern. All the $\mathrm{F}_{2}$ segregating plants of a cross were tagged and observations were recorded periodically till confirmation of the phenotype.

\section{Statistical analysis:}

Chi-square method was used as per Singh and Chaudhary (1977) to test the goodness of fit for segregating ratios observed for branching and bearing pattern in Guar.

The chi square statistic is defined as

$$
\chi 2=\Sigma \frac{\left(\mathbf{O}_{i}-E_{i}\right)^{2}}{E_{i}}
$$

where, Oi is the observed number of cases in category $i$, and $\mathrm{Ei}$ is the expected number of cases in category $i$.

\section{Results and Discussion}

PNB $\times$ CAZG-16-10-3

In a cross $\mathrm{PNB} \times \mathrm{CAZG}-16-10-3$ parent PNB is single stem and regular in bearing but parent CAZG-16-10-3 branched (bushy) in nature. All F1 plants of the cross had single stem regular trait but in $\mathrm{F}_{2}$ segregating population a total of 58 plants were detected as single stem while 38 plants were branched and 8 plants exhibited basal revealing gene interaction ratio of 9:6:1 for single stem, branched and basal plants. The $\chi^{2}$ test for goodness- of- fit gave 0.36 value having the probability of 0.8-0.9 (Table 1). This suggested that two pairs of genes were segregating with polymeric gene effects where both the genes are required in dominant form to produce single stem (unbranched) trait. Table 1. Chi-squre analysis of $\mathrm{F}_{2}$ segregating population of a cross PNB $\times$ CAZG-16-10-3

\begin{tabular}{lccccc}
\hline $\mathrm{PNB} \times$ CAZG-16-10-3 & $\mathrm{O}_{\mathrm{i}}$ & $\mathrm{E}_{\mathrm{i}}$ & $\mathrm{O}_{\mathrm{i}}-\mathrm{E}_{\mathrm{i}}$ & $\left(\mathrm{O}_{\mathrm{i}}-\mathrm{E}_{\mathrm{i}}\right)^{2}$ & $\left(\mathrm{O}_{\mathrm{i}}-\mathrm{E}_{\mathrm{i}}\right)^{2} / \mathrm{E}_{\mathrm{i}}$ \\
\hline Single stem & 58 & 58.5 & -0.5 & 0.25 & 0.004 \\
Branched & 38 & 39 & -1 & 1 & 0.025
\end{tabular}




\begin{tabular}{cccccc} 
Basal & 8 & 6.5 & 1.5 & 2.25 & 0.34 \\
& 104 & & & $\mathrm{x}^{2}$ & 0.369 \\
& & & $\mathrm{P}$ & $0.8-0.9$ \\
\hline
\end{tabular}

\#Expected ratio 9:6:1, non allelic gene interaction, polymeric gene effect

\section{IDB-29-2 $\times$ BSL}

In the cross IDB-29-2 $\times$ BSL, parent IDB29-2 is single stem and regular in bearing but parent BSL bears branches on basal nodes only where upper part remains branchless with regular podding in nature. All the $\mathrm{F}_{1}$ plants of this cross were found single stem regular. In $\mathrm{F}_{1}$ single stem trait behaved as dominant on basal trait. In $F_{2}$ population a total of 130 Table 2.Chi-squre analysis of $\mathrm{F}_{2}$ segregating population of a cross IDB-29-2 $\times$ BSL

\begin{tabular}{lccccc}
\hline IDB-29-2 $\times$ BSL & $\mathrm{O}_{\mathrm{i}}$ & $\mathrm{E}_{\mathrm{i}}$ & $\mathrm{O}_{\mathrm{i}}-\mathrm{E}_{\mathrm{i}}$ & $\left(\mathrm{O}_{\mathrm{i}}-\mathrm{E}_{\mathrm{i}}\right)^{2}$ & $\left(\mathrm{O}_{\mathrm{i}}-\mathrm{E}_{\mathrm{i}}\right)^{2} / \mathrm{E}_{\mathrm{i}}$ \\
\hline Single stem & 130 & 127.5 & 2.5 & 6.25 & 0.049 \\
Basal & 40 & 42.5 & -2.5 & 6.25 & 0.147 \\
Total & 170 & & & $\mathrm{X}^{2}$ & 0.196 \\
& & & & $\mathrm{P}$ & $0.5-0.7$ \\
\hline
\end{tabular}

\#Expected ratio 3:1 Allelic gene interaction, monogenic

\section{Cross F5 × RGC-1066}

An F2 population was raised involving parents $\mathrm{F}_{5} \times \mathrm{RGC}-1066$ where, parent $\mathrm{F}_{5}$ is having branched trait and parent RGC-1066 is single stem intermittent. In a segregating population of this cross total of 85 plants were plants were detected as single stem regular while 40 plants exhibited basal branching. Trait seems to follow simple Mendelian monogenic inheritance. A goodnees - of - fit test revealed a good fit of ratios in 3:1 segregation pattern for single stem regular and basal plants having a probability of 0.5-0.7 (Table 2). Single stem apparently was dominant and inherited in a monogenic way.

Table 3. Chi-squre analysis of $\mathrm{F}_{2}$ segregating population of a cross $\mathrm{F} 5 \times$ RGC-1066

\begin{tabular}{lccccc}
\hline F5 $\times$ RGC-1066 & $\mathrm{O}_{\mathrm{i}}$ & $\mathrm{E}_{\mathrm{i}}$ & $\mathrm{O}_{\mathrm{i}}-\mathrm{E}_{\mathrm{i}}$ & $\left(\mathrm{O}_{\mathrm{i}}-\mathrm{E}_{\mathrm{i}}\right)^{2}$ & $\left(\mathrm{O}_{\mathrm{i}}-\mathrm{E}_{\mathrm{i}}\right)^{2} / \mathrm{E}_{\mathrm{i}}$ \\
\hline Branched & 85 & 91.68 & -6.68 & 44.62 & 0.48 \\
Single stem & 32 & 30.56 & 1.44 & 2.07 & 0.067 \\
Basal & 46 & 40.75 & 5.25 & 27.56 & 0.67 \\
& 163 & & & $\mathrm{X}^{2}$ & 1.217 \\
& & & & $\mathrm{P}$ & $0.5-0.7$
\end{tabular}

\#Expected ratio 9:3:4, supplementary gene effect

\section{Conclusion}

The inheritance of two characters namely branching behavior and bearing habit was studied in clusterbean for $\mathrm{F}_{2}$ population. These traits were controlled by two pairs of genes in three segregating $\mathrm{F}_{2}$ population viz., $\mathrm{PNB} \times$ CAZG-16-10-3 (9:6:1), F5 × RGC-1066 (9:3:4), while IDB-29-2 $\times$ BSL branching detected as branched, while 32 plants detected as single stem and 46 plants were exhibited basal. A ratio of 9:3:4 for branched, single stem and basal revealed by chi-sqaure test (Table 3). This suggested that two pairs of gene interact with supplementary gene effect. 


\section{Reference}

Boghara MC, Dhaduk HL, Kumar S, Parekh MJ, Patel NJ \& Sharma R. 2016. Genetic divergence, path analysis and molecular diversity analysis in cluster bean (Cyamopsis tetragonoloba $\mathrm{L}$ Taub.). Industrial crops and products, 89: 468477.

Hymowitz T \& Matlock RS. 1963. Guar in the United States, Oklahoma Agricultural Experiment Station Technical Bulletin. 611: 1-34.

Mahalanobis PC. 1936. On the generalized distance in statistics. Proceedings National Institute of Science, India. 2: 49-55.
Pathak R \& Singh M. 2010. Genetic divergence in clus-terbean (Cyamopsis tetragonoloba (L.) Taub.) for seed yield and gum content under rainfed conditions, Indian J. Agricultural Science, 79 (7): 559- 561.

Saini ML, Arora RN \& Paroda RS. 1981. Morphology of three species of genus Cyamopsis. Guar Newsl. 2, 7-11.

Sharma P \& Gummagolmath. 2012. Reforming guar industry in India: issues and strategies. Agric. Econ. Res. Rev., 25: 37-48. 